\title{
Pemberian Motivasi Orang Tua Dalam Menggosok Gigi Pada Anak Usia Prasekolah Terhadap Timbulnya Karies Gigi
}

\author{
${ }^{1}$ Avi Dian Sari, ${ }^{2}$ Intan Fazrin, ${ }^{3}$ Heri Saputro \\ STIKes Surya Mitra Husada Kediri \\ fazrin_smile@yahoo.co.id
}

\begin{abstract}
Dental caries is a disease found in dental hard tissues, namely email, dentin, cementum which experienced chronic regressive process. The cause of dental caries are lazy or wrong in brushing teeth. The purpose of this study was to determine the relationship of giving motivation by parents in brushing tooth in preschool children on the rise of dental caries in Dharma Wanita I Kindergarten Singonegaran Kediri.

The study design was cross sectional. The study population were all parents of preschool students as much as 85 respondents. The sample size of 70 respondents taken with Stratified Random Sampling technique. The independent variable is giving motivation by parents, while the dependent variable was the rise of dental caries. Results of analysis using the Spearman rho.

The results were obtained mostly parents motivation lacking as many as 42 respondents (60\%), and observations obtained 64 children (91\%) experienced caries.

Results Spearman rho value 0,000 known $\rho<0,05$ then $H_{0}$ is rejected, which means there is a significant correlation of giving motivation by parents with the rise of dental caries.
\end{abstract}

Keywords: Motivation By Parents, Dental Caries, Preeschool Children

Received August 15, 2017; Revised September 07, 2017; Accepted October 01, 2017

How to Cite: Sari, A.D., Fazrin, I \& Saputro, H. (2017). Pemberian Motivasi Orang Tua Dalam Menggosok Gigi Pada Anak Usia Prasekolah Terhadap Timbulnya Karies Gigi. Journal Of Nursing Practice. 1(1). 33-39. 


\section{PENDAHULUAN}

Kesehatan gigi dan mulut bagi usia prasekolah merupakan hal yang perlu mendapat perhatian serius bagi orang tua, tenaga kesehatan baik dokter maupun perawat, sebab karies gigi masih merupakan masalah utama kesehatan mulut di berbagai negara. Perawatan gigi yang kurang baik atau tidak adekuat menyebabkan masalah yang paling umum dari seluruh masalah kesehatan gigi pada masa kanak-kanak. Penyakit gigi masih sering diabaikan oleh banyak orang tua, mereka menganggap kerusakan gigi merupakan hal yang biasa terjadi pada anak. Rendahnya motivasi orang tua menyebabkan kegiatan menggosok gigi pada anak menjadi kurang maksimal. Kurangnya motivasi yang diberikan membuat anak tidak memperhatikan ketika orang tua memberikan perintah untuk gosok gigi ${ }^{5}$.

Karies gigi merupakan penyakit yang terdapat pada jaringan keras gigi yaitu email, dentin dan sementum yang mengalami proses kronis regresif. Karies gigi terjadi karena adanya proses interaksi antara bakteri pada permukaan gigi. Komponen karbohidrat yang dapat difermentasikan oleh bakteri plak menjadi asam,terutama asam laktat dan asam asetat, kondisi asam seperti ini sangat disukai oleh bakteri kariogenik yang berada di rongga mulut dikenal dengan nama Streptococcus Mutans (SM). Proses ini ditandai dengan adanya demineralisasi jaringan keras gigi dan rusaknya bahan organik akibat terganggunya keseimbangan email dan sekelilingnya, menyebabkan terjadinya invasi bakteri yang dapat berkembang ke jaringan periapeks sehingga dapat membentuk mineral disebut dengan karang gigi yang meningkatkan resiko karies gigi dan menimbulkan rasa sakit dan nyeri (Sugeng, 2008). Karies gigi dapat disebabkan oleh beberapa faktor pencetus. Faktor yang menyebabkan terjadinya karies gigi yaitu hospes (saliva dan gigi), mikroorganisme, substrat, sebagai faktor tambahan yaitu waktus.

Berdasarkan hasil studi pendahuluan yang dilakukan peneliti tentang pemberian motivasi orang tua dalam menggosok gigi pada anak usia prasekolah dengan timbulnya karies gigi di TK Dharma Wanita Singonegaran I pada 28 Oktober 2015 didapatkan 37 anak mengalami karies gigi. Dari hasil wawancara yang dilakukan terhadap 12 orang tua didapatkan bahwa beberapa anak mengalami permasalahan pada giginya. Tujuh orang tua diantaranya mengatakan anak mereka masih jarang-jarang untuk menggosok gigi. Bahkan jika tidak diingatkan dan disuruh anak cenderung malas dan tidak menggosok gigi. Dan lima orang tua yang lain mengemukakan bahwa anaknya mengalami karies gigi, tetapi mereka menganggap bahwa karies gigi bukan merupakan masalah serius bagi kesehatan mulut anak dan akan sembuh dengan sendirinya.

Akibat karies gigi yang berkepanjangan pada anak akan menyebabkan banyak masalah kesehatan, tentunya masalah infeksi pada gigi. Jika tidak ditangani, penyakit ini akan meyebabkan nyeri, gangguan tidur, penanggalan gigi, infeksi, berbagai kasus berbahaya dan bahkan kematian. Penyebab penyakit tersebut karena malas atau salah dalam menyikat gigi, kurangnya perhatian dalam kesehatan gigi dan mulut, bahkan tidak ada dukungan orang tua untuk menyikat gigi (Listono, 2012). Orang tua sebagai orang terdekat dan memiliki tanggung jawab yang besar bagi anak merupakan pendukung utama dalam pelaksanaan kesehatan gigi dan mulut. Bukan hanya memfasilitasi dengan menyediakan sikat gigi dan pasta gigi saja, tetapi orang tua juga memiliki peranan dalam memberi dukungan agar anak termotivasi untuk menggunakan dan melaksanakannya ${ }^{11}$.

Motivasi adalah kecenderungan yang timbul pada diri seseorang secara sadar maupun tidak sadar melakukan tindakan dengan tujuan tertentu atau usaha-usaha yang menyebabkan seseorang atau kelompok orang tergerak melakukan sesuatu karena ingin mencapai tujuan yang dikehendaki ${ }^{9}$. 
Berbagai faktor penyebab karies, pelaksanaan orang tua dapat dilakukan yaitu dengan memberikan motivasi kepada anak agar anak mau untuk menggosok gigi.Menggosok gigi adalah cara yang dikenal umum oleh masyarakat untuk menjaga kebersihan gigi dan mulut dengan maksud agar terhindar dari penyakit gigi dan mulut ${ }^{1}$. Untuk itu peran orang tua sangatlah penting dalam memotivasi anak menggosok gigi dengan menciptakan suasana gosok gigi yang menyenangkan agar anak menggosok gigi dengan senang hati, membuat kegiatan gosok gigi dengan permainan supaya dapat merangsang keinginan anak untuk gosok gigi, ataupun memberikan pujian maupun hadiah bagi anak apabila dia telah berhasil untuk rajin gosok gigi ${ }^{10}$.

\section{METODE PENELITIAN}

Dalam penelitian ini menggunakan desain kuantitatif penelitian korelasional dengan menggunakan metode cross sectional. Populasi penelitian ini adalah semua orang tua siswa prasekolah di TK Dharma Wanita Singonegaran I Kota Kediri yang berjumlah 85 responden. Teknik pengambilan sampel dalam penelitian ini adalah Stratified Random Sampling. Jumlah sampel yang didapatkan sebesar 70 responden.

Instrumen penelitian ini menggunakan kuesioner untuk mengetahui pemberian motivasi orang tua yang diberikan, dan observasi untuk mengetahui status gigi pada anak usia prasekolah. Proses selanjutnya yaitu analisa data yang diuji perangkat lunak SPSS dengan uji statistik Spearman rho $\alpha=0,05$ untuk mengetahui apakah ada hubungan pemberian motivasi orang tua dalam menggosok gigi pada anak usia prasekolah terhadap timbulnya karies gigi di TK Dharma Wanita Singonegaran I Kota Kediri.

\section{HASIL DAN PEMBAHASAN}

\section{A. HASIL PENELITIAN}

a. Data Umum

Dalam pembahasan hasil penelitian ini, peneliti akan menjabarkan data-data yang diperoleh dari responden melalui penyebaran kuesioner. Data umum merupakan data responden yang mengacu kepada identitas atau karakteristik responden. Dalam hal ini peneliti mengumpulkan data berupa status dalam keluarga, umur orang tua, pendidikan, status pekerjaan, usia anak, jenis kelamin anak, kelas, status gigi.

b. Data Khusus

Data khusus akan menyajikan karakteristik pemberian motivasi orang tua dalam menggosok gigi dengan timbulnya karies gigi pada anak usia prasekolah.

Tabel 1 Distribusi frekuensi responden berdasarkan motivasi orang tua di TK Dharma Wanita Singonegaran I Kota Kediri

\begin{tabular}{lcc}
\hline Kategori & Jumlah & $\begin{array}{c}\text { Presentase } \\
(\%)\end{array}$ \\
\hline Baik & 7 & 10 \\
Cukup & 21 & 30 \\
Kurang & 42 & 60 \\
\hline Jumlah & 70 & 100 \\
\hline
\end{tabular}

Berdasarkan Tabel 1 dapat diketahui bahwa sebagian besar responden memiliki motivasi kurang terhadap timbulnya karies gigi pada anak yaitu ebanyak $60 \%$ (42 responden).

Tabel 2 Distribusi frekuensi responden berdasarkan timbulnya karies gigi pada anak di TK Dharma Wanita Singonegaran I Kota Kediri

\begin{tabular}{ccc}
\hline Status Gigi & Jumlah & Presentase(\%) \\
\hline
\end{tabular}




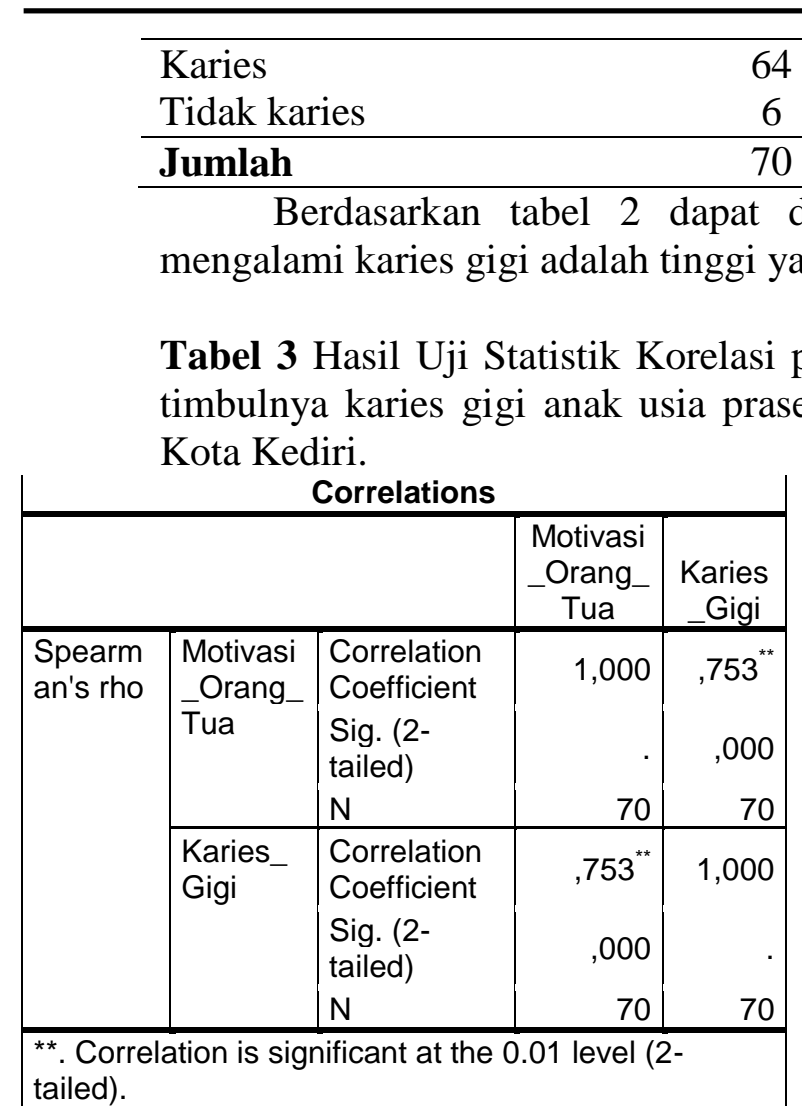

Berdasarkan tabel 3 dapat diketahui hasil uji statistik yang dilakukan dengan menggunakan uji Spearman rho kepada 70 responden pada tanggal 29 April 2016 di TK Dharma Wanita Singonegaran I Kota Kediri didapatkan $\rho$ value $=0,000$ dengan koefisien korelasi sebesar 0,753 dan $\alpha=0,05$ karena nilai $\rho$ value $0,000<0,05$ maka $\mathrm{H}_{0}$ ditolak yang berarti adal hubungan yang signifikan pemberian motivasi orang tua dengan timbulnya karie gigi pada anak usia prasekolah di TK Dharma Wanita Singonegaran I Kota Kediri.

\section{PEMBAHASAN}

Pemberian Motivasi Orang Tua Dalam Menggosok Gigi Pada Anak Usia Prasekolah di TK Dharma Wanita Singonegaran I Kota Kediri

Berdasarkan hasil penelitian yang telah dilakukan pada tanggal 29 April 2016 di Taman Kanak-kanak Dharma Wanita Singonegaran I Kota Kediri didapatkan orang tua yang memberikan motivasi baik sebanyak 7 responden (10\%), sedangkan motivasi cukup 21 responden (30\%), dan motivasi kurang 42 responden $(60 \%)$. Hal ini menunjukkan bahwa kurangnya pemberian motivasi orang tua dalam menggosok gigi terhadap timbulnya karies gigi pada anak usia prasekolah.

Hal tersebut dikarenakan motivasi orang tua merupakan faktor yang penting bagi anak dalam melakukan kegiatan baik di rumah maupun di luar rumah. Orang tua sebagai tokoh sentral dalam tahap perkembangan seorang anak, maka diwajibkan selalu membimbing dan mendukung kegiatan anak di dalam maupun luar sekolah, sehingga orang tua perlu menguasai berbagai pengetahuan ketrampilannya ${ }^{12}$. Orang tua memiliki tanggung jawab yang sangat besar dalam menjaga kesehatan anggota keluarganya. Orang tua harus selalu memperhatikan perkembangan anak baik makanan dan kebersihan serta kesehatan anak. Orang tua memberikan pengaruh yang sangat besar tehadap perilaku anak, sebab orang tua merupakan figur pertama yang menjadi contoh bagi anak-anaknya. Orang tua berkewajiban memberikan bimbingan, perhatian, pengawasan dan mengajarkan hal-hal positif serta kasih 
sayang bagi anak-anaknya. Hal yang dapat dilakukan antara lain membantu anak dalam kegiatan menggosok gigi terutama pada anak di bawah usia 10 tahun, karena anak belum memiliki kemampuan motorik yang baik untuk menggosok gigi terutama jika dilakukan mandiri ${ }^{6}$.

Menurut Uno (2008) setiap individu memiliki kondisi internal, dimana kondisi tersebut ikut berperan dalam aktivitas dirinya sehari-hari. Salah satu kondisi internal tersebut adalah "motivasi". Motivasi adalah dorongan dasar yang menggerakkan seseorang untuk bertingkah laku. Dorongan tersebut berada pada diri seseorang yang menggerakkan untuk melakukan sesuatu yang sesuai dengan dorongan dalam dirinya. Waktu menggosok gigi yang tepat adalah pagi setelah sarapan dan malam sebelum tidur. Waktu tidur produksi air liur berkurang sehingga menimbulkan suasana asam di mulut. Sisa-sisa makanan pada gigi jika tidak dibersihkan, maka mulut semakin asam dan kuman pun akan tumbuh subur membuat lubang pada gigi. Sifat asam ini bisa dicegah dengan menggosok gigi. Menggosok gigi adalah cara yang dikenal umum oleh masyarakat untuk menjaga kebersihan gigi dan mulut dengan maksud agar terhindar dari penyakit gigi dan mulut ${ }^{4}$.

\section{Timbulnya Karies Gigi Pada Anak Usia Prasekolah di TK Dharma Wanita Singonegaran I Kota Kediri}

Dari hasil observasi menggunakan lembar odontogram yang dilakukan oleh dokter gigi pada tanggal 29 April 2016 di TK Dharma Wanita Singonegaran I Kota Kediri menunjukkan bahwa mayoritas anak memiliki status gigi karies, dengan jumlah anak dengan gigi karies sebesar 64 anak (91\%) dan 6 anak (9\%) bebas karies.

Sumber kuman paling besar adalah di dalam mulut. Anak usia prasekolah sangat rentan terkena karies, hal-hal yang dapat menyebabkan karies diantaranya susunan gigi, umur, jenis kelamin, orang tua, makanan ${ }^{8}$. Gigi susu lebih mudah terserang karies daripada gigi tetap, hal ini dikarenakan gigi susu lebih banyak mengandung bahan organik dan air daripada mineral, dan secara kristalografis mineral dari gigi tetap lebih padat bila dibandingkan dengan gigi susu. Alasan mengapa susunan kristal dan mineralisasi gigi susu kurang adalah pembentukan maupun mineralisasi gigi susu terjadi dalam kurun waktu 1 tahun, sedangkan pembentukan dan mineralisasi gigi tetap 7-8 $\operatorname{tahun}^{2}$. Dari faktor penyebab karies, terdapat 64 anak yang mengalami karies disebabkan motivasi orang tua yang kurang karena pendidikan orang tua yang rendah dan usia orang tua menyebabkan keterhambatan dalam menangkap informasi secara cepat serta penurunan IQ orang tua.

Pekerjaan wiraswasta yang menyita waktu menyebabkan kehadiran orang tua di rumah menjadi berkurang. Sedangkan untuk 6 anak yang berstatus tidak karies memiliki orang tua dengan pendidikan SMA dan Perguruan Tinggi. Semakin tinggi tingkat pendidikan orang tua, maka semakin mudah untuk menangkap informasi yang diterima. Status pekerjaan sebagai PNS akan membuat orang tua lebih peka dan intensif untuk mencari tahu tentang bagaimana caranya menggosok gigi agar anak tidak mengalami karies. Untuk status orang tua yang tidak bekerja akan memiliki waktu yang lebih banyak di rumah untuk menjalani kegiatan sehari-hari bersama dengan anak, sehingga pengawasan dalam menggosok gigi lebih optimal.

Namun dalam tabel 4.7 didapatkan untuk status orang tua yang tidak bekerja terdapat 12 orang tua yang memiliki motivasi kurang, hal ini disebabkan karena sebagian besar orang tua memiliki pendidikan dasar. Orang dengan pendidikan yang rendah cenderung memiliki pengetahuan yang kurang, sehingga mereka kurang peka terhadap informasi-informasi yang diterima dan menganggap kurang penting akan hal menggosok gigi. 
Pemberian Motivasi Orang Tua Dalam Menggosok Gigi Pada Anak Usia Prasekolah Terhadap Timbulnya Karies Gigi di TK Dharma Wanita Singonegaran I Kota Kediri

Hasil uji statistik yang dilakukan dengan menggunakan uji Spearman Rho kepada 70 responden pada tanggal 29 April 2016 di TK Dharma Wanita Singonegaran I Kota Kediri didapatkan $\rho$ value $=0,000$ dengan koefisien korelasi 0,753 dan $\alpha=0,05$, karena nilai $\rho$ value $=0,000<0,05$ maka $\mathrm{H}_{0}$ ditolak yang berarti ada hubungan yang signifikan antara pemberian motivasi orang tua dalam menggosok gigi terhadap timbulnya karie gigi di TK Dharma Wanita Singonegaran I Kota Kediri. Cukup kuat hubungan berdasarkan nilai koefisien korelasi yang didapatkan hubungan terbentuk dari kedua variabel dikategorikan kuat yang berarti pemberian motivasi orang tua dalam menggosok gigi pada anak usia prasekolah terhadap timbulnya karies gigi saling berkaitan dan penting.

Anak akan dapat menyadari apa gunanya menggosok gigi itu, jika diberi perangsang atau motivasi. Maka motivasi orang tua merupakan faktor yang memegang peran penting terhadap keberlangsungan kesehatan gigi anak ${ }^{3}$.

Menurut peneliti pentingnya keluarga dalam mendukung kegiatan anak dalam menggosok gigi, mengingat hal ini maka tanpa adanya motivasi orang tua yang kuat seorang anak akan malas untuk menggosok gigi.

Dari uraian di atas dapat disimpulkan bahwa pemberian motivasi orang tua yang kurang khususnya pemberian bimbingan, penyediaan fasilitas, pemberian hukuman, pengawasan, dan pemberian hadiah yang dapat mempengaruhi kegiatan gosok gigi dan kejadian karies gigi yang tinggi.

\section{KESIMPULAN DAN SARAN}

\section{A. Kesimpulan}

Ada hubungan atara pemberian motivasi orang tua dalam menggosok gigi pada anak usia prasekolah terhadap timbulnya karies gigi di TK Dharma Wanita Singonegaran I Kota Kediri.

B. Saran

Diharapkan dapat dijadikan gambaran bagi TK Dharma Wanita Singonegaran I Kota Kediri untuk lebih dapat meningkatkan kerja sama melibatkan orang tua untuk meningkatkan motivasi yang baik, membuat jadwal kegiatan menggosok gigi dan screening 6 bulan sekali di Taman Kanak-kanak untuk meminimalkan timbulnya karies gigi.

\section{DAFTAR PUSTAKA}

Alpers, Ann. 2006. Buku Ajar Pediatri $\quad$ Rudolph, edisi 20 volume 2. Jakarta: EGC.

Arep, Ishak, dkk. 2003. Manajemen Motivasi. Jakarta: PT. Gramedia Widiasarana Indonesia.

Budiman, C, M. 2009. Manfaat Berbagai Jenis Pasta Gigi, available from: http://wwwfajar.co.id/news.php?n ewsid=12984

Edwina, Sally Joyston. 2013. Dasar-dasar Karies Penyakit dan Penanggulangan. EGC: Jakarta. 
Halimsyah, dkk. 2008. Perkembangan Motorik Halus Prasekolah https://docs.google.com diakses 10 Mei 2016.

Hamzah B, Uno. 2008. Model

Pembelajaran. Jakarta : Bumi

Aksara.

Listiono, B. 2012. Kesehatan Gigi Dan $\quad$ Mulut. $\quad$ Diakses $\quad$ pada $\quad$ tanggal 24 Januari2016pukul15.10.http://Ww w.litbang.tangerangkota.go.id/ind ex.PHP/detail_kesehatan_gigi_m ulut

Poerwadarminta. W. J. S. 2006. Kamus $\quad$ Umum Bahasa Indonesia. Jakarta: $\quad$ PN Balai Pustaka.

Riyanti, Eriska. 2005. Pengenalan dan Perawatan Kesehatan Gigi Anak Sejak Dini. Disajikan dalam seminar sehari kesehatan.- psikologi anak. Minggu 29 Mei 2005 di Gedung Lab Klinik Utama Pramita.

Santoso, Soegeng. 2009. Materi Pokok Kesehatan dan Gizi. Universitas Terbuka: Jakarta.

Wahyu, dkk. 2013. "Hubungan Dukungan Keluarga Terhadap Perilaku Menjaga

Kesehatan Gigi Anak Usia Prasekolah di Taman Kanak-kanak Ar-Ridlo

Kecamatan Blimbing Kota Malang. Diakses pada 10 Mei 2016.

http://old.fk.ub.ac.id 